\title{
UPAYA PENINGKATAN KETERAMPILAN PRAKTIK UNTUK MENGOPTIMALKAN METODE EKSPERIMEN/NON-EKSPERIMEN PADA SISWA KELAS XII IPA-2
}

\author{
JONI ALI \\ SMAN 1 Batanghari, Kabupaten Lampung Timur, Lampung \\ E-mail : joniali466@gmail.com
}

\begin{abstract}
This study aims to improve student practical skills and student learning outcomes, as well as other aspects, through optimizing the use of experimental / non-experimental methods. There is also an increase in teacher creativity and renewal in the management of the biology learning process. This research was conducted at SMA Negeri 1 Batanghari, class XII IPA-2, with 29 students as research subjects. Through this research, it is hoped that teachers will be able to play a role as learning innovators. With the increased creativity of teachers in the implementation of learning activities with the experimental / non-experimental method, the difficulty of students in using laboratory tools / materials, analyzing pictures / diagrams / schemes according to the pictures on the Student Worksheet (LKS), can optimize the use of learning time. in achieving the expected learning objectives. The results showed that by optimizing the use of the experimental / non-experimental method, students' practical skills could improve (through the use of tools / materials, analyzing pictures / diagrams / schemes), and student learning outcomes, as well as other aspects (cheerfulness, enthusiasm, attention and activity).
\end{abstract}

Keywords: Experimental/non-experimental methods, practical skills, using tools/materials, analyzing pictures/diagrams/schemes.

\section{PENDAHULUAN}

Untuk mengatasi kesulitan siswa, guru dalam melaksanakan kegiatan pembelajaran harus memiliki pengetahuan yang cukup. Guru harus memberikan penjelasan tentang cara merangkai alat-alat atau menggunakan alat/bahan sesuai dengan yang ada di LKS, dalam bentuk petunjuk yang mudah dipahami oleh siswa. Media pembelajaran, yang berupa alat-alat laboratorium, sangat diperlukan dalam kegiatan pembelajaran yang menggunakan metode eksperimen/non eksperimen. Berdasarkan pengalaman siswa mengalami kesulitan memahami konsep teori evolusi, dan bioteknologi terutama KD 3.9. Begitu juga dengan KD 3.10, karena hal ini membutuhkan pengetahuan dasar yang cukup dan pengalaman lapangan. Dalam konteks ini, diharapkan siswa dapat menemukan kesesuaian antara teori yang diterima dengan hasil eksperimen/non-eksperimen yang dilaksanakan.

Dengan demikian kegiatan pembelajaran melalui metode eksperimen/non-eksperimen dapat memanfaatkan waktu secara lebih efektif.Selanjutnya SMAN 1 Batanghari belum mempunyai laboratorium khusus Biologi dan peralatan belum lengkap, sehingga guru harus merancang serta merekayasa alat agar pratikum dapat berlangsung lancar dan sukses. Ada beberapa masalah yang diduga sebagai alasan perlunya diadakan PTK ini, yaitu siswa: 1) kesulitan memahami gambar/diagram yang berhubungan dengan variabel-variabel dalam percobaan, 2) masih kesulitan merangkai atau menggunakan alat/bahanatau sesuai dengan gambar/diagram tanpa bantuan guru, 3) kesulitan melaksanakan eksperimen/non eksperimen sesuai petunjuk LKS, 4) belum memiliki percaya diri, 5) selalu ragu-ragu dalam bertindak, 6) kesulitan menjawab pertanyaan-pertanyaan di LKS, 7) belum terbiasa melakukan praktik di laboratorium atau di lapangan.

Metode pemecahan masalah yang akan digunakan dalam PTK ini, yaitu dengan meningkatkan Keterampilan siswa merangkai atau menggunakan alat/bahandan peningkatan pemahaman dan penguasaan konsep yang dipelajarimelalui metode eksperimen/non 
eksperimen. Dengan model pembelajaran ini, diharapkan pelaksanaan praktik, keterampilan siswa dalam merangkai atau menggunakan alat/bahan meningkat, dan dengan gambar/diagram konsep danpetunjuk pelaksanaan LKS eksperimen/non-eksperimen yang jelas, sehingga pelaksanaan metode eksperimen/non-eksperimen dapat terlaksana secara optimal. Penelitian ini direncanakan terbagi kedalam tiga siklus, setiap siklus dilaksanakan mengikuti prosedur perencanaan (planning), tindakan (acting), pengamatan (observing), dan refleksi (reflecting). Melalui tiga siklus tersebut dapat diamati peningkatan keterampilan siswa.

Penelitian bertujuan untukmembantu siswa meningkatkan: 1) keterampilan merangkai atau menggunakan alat/bahan, kemampuan menganalisa gambar/diagram, penuh percaya diri, dan tidak ragu-ragu dalam bertindak, serta kualitas hasil pembelajaran Biologi,dan 2) membantu guru agar dapat lebih mengoptimalkan penggunaan metode eksperimen/noneksperimen dalam pembelajaran Biologi. Manfaat penelitian dapat meningkatkan: Keaktifan siswa dalam mengerjakan tugas kelompok, Keberanian siswa dalam mengungkapkan ide, pendapat, pertanyaan, Keterampilan siswa dalam merangkai atau menggunakan alat/bahan di laboratorium maupun di luar, Kualitas pembelajaran Biologi, Hasil belajar siswa dalam mata pelajaran Biologi, ditemukan strategi pembelajaran yang tepat tidak konvensional, tetapi bersifat variatif dan Proses belajar mengajar biologitidak lagi monoton.

Rezba dkk. (1995) mendeskripsikan keterampilan proses Biologi yang harus dikembangkan pada diri siswa mencakup kemampuan yang pailng sederhana yaitu mengamati, mengukur sampai dengan kemampuan tertinggi yaitu kemampuan bereksperimen atau non eksperimen. Menurut Bryce dkk. (1990) keterampilan proses biologi mencakup keterampilan dasar (basic skill) sebagai kemampuan terendah, kemudian diikuti dengan keterampilan proses (process skill). Sebagai keterampilan tertinggi adalah keterampilan investigasi (investigation skill). Keterampilan dasar mencakup: (a) melakukan pengamatan (observational skill), (b) mencatat data (recording skill), (c) melakukan pengukuran (measurement skill), (d) mengimplementasikan prosedur (procedural skill), dan (e) mengikuti instruksi (following instructions). Keterampilan proses meliputi: (a) menginferensi (skill of inference) dan (b) menyeleksi berbagai cara/prosedur (selection of procedures). Keterampilan investigasi berupa keterampilan merencanakan dan melaksanakan serta melaporkan hasil investigasi. Keterampilan tersebut juga harus didasari oleh sikap ilmiah seperti sikap antusias, ketekunan dan kejujuran.

Perkembangan Aspek Psikomotor. Proses pembelajaran sains seharusnya tidak saja menyangkut olah pikir (mind on) akan tetapi juga memperhatikan olah tangan (hands-on) yang berupa kerja praktek. (Madya, Suwarsih, 2007). Melalui kerja praktek ini, siswa dapat mengembangkan Keterampilan proses sains, kompetensi psikomotoriknya bahkan ada kemungkinan juga dapat berkembangnya aspek afektif. Kegiatan praktek dapat berupa demonstrasi yanng dilakukan oleh guru, oleh kelompok siswa baik didalam kelas, dilaboratorium maupun di lapangan.Sesuai dengan tahap perkembangan kognitif siswa, aspek psikomotorik yang dapat dilatihkan kepada siswa SMA adalah yang mendukung pengembangan keterampilan proses sains dasar, yaitu kompetensi menggunakan alat ukur dan mengoperasionalkan alat-alat sederhana.

Metode Eksperimen/non-eksperimen. Berdasarkan kenyataan, siswa dalam mempelajari Biologikurang mampu memahami konsep-konsep Biologi. Untuk mengatasi masalah diatas, penelitian ini memfokuskan penggunaan metode eksperimen/non-eksperimen melalui Lembar Kerja Siswa (LKS). Metode ini didasarkan pada pemahaman bahwa Biologi mempelajari tentang gejala, alat pembelajaran Biologi yang dikemukakan oleh Brokhous (1972) dalam Herbert Oruyes (1996:3).Metode eksperimen/non-eksperimen adalah cara penyajian pelajaran dimana siswa melakukan percobaan agar mengalami dan membuktikan sendiri materi yang dipelajari (Soedirman:115). Siswa diberi kesempatan mengalami sendiri, mengikuti proses, mengamati, menganalisis, dan menarik kesimpulan dari materi yang diamati. Dengan demikian, siswa dituntut aktif dalam menarik kebenaran, mengolah dan 
membuktikan sendiri hukum atau dalil, serta mengambil kesimpulan atas proses praktikum yang dialaminya (Soedirman:116). Dalam metode eksperimen/non-eksperimen ini, guru tetap meminpin dan membimbing kerja siswa.

Berdasarkan latar belakang permasalahan diatas, peneliti tertarik untuk mengadakan penelitian tindakan kelas (PTK) untuk mengoptimalkan metode eksperimen/non-eksperimen. Dengan judul penelitian : “Upaya Peningkatan Keterampilan Praktik Untuk Mengoptimalkan Metode Eksperimen/non-eksperimen Pada Siswa Kelas XII IPA-2 SMAN 1 Batanghari ”.

\section{METODE PENELITIAN}

Subyek dalam penelitian ini adalah siswa kelas XII IPA-2 SMAN 1 Batanghari berjumlah 29 orang. Penelitian ini dilaksanakan melalui tiga siklus untuk melihat peningkatan Keterampilan siswa dalam merangkai atau menggunakan alat/bahanatau menganalisa gambar/diagram/ skema untuk mengoptimalkan metode eksperimen/non eksperimen. Menurut Madya, Suwarsih, 2007), sebelum PTK dilaksanakan dibuat berbagai input instrumental yang akan digunakan untuk memberi perlakuan dalam PTK. Selain itu juga dibuat perangkat pembelajaran yang berupa: (1) Lembar Kerja Siswa (LKS); (2) Lembar Pengamatan Pelaksanaan Eksperimen/non-eksperimen; (3) Lembar Hasil Evaluasi. Dalam persiapan juga disusun daftar nama kelompok eksperimen/non-eksperimen yang dibuat secara heterogen. Sumber data dalam penelitian ini terdiri dari beberapa sumber, yakni siswa,guru dan teman sejawat.Tehnik pengumpulan data dalam penelitian ini adalah tes, observasi, kuesioner dan diskusi.Alat pengumpul data dalam PTK ini meliputi tes, observasi, kuesioner. Indikator Kinerja selain siswa adalah guru, karena guru merupakan fasilitator yang sangat berpengaruh terhadap kinerja siswa. Siswa,berupa nilairata-rata ulangan harian. Fungsi Observasi: untuk melihat peningkatan Keterampilan siswa dalam merangkai atau menggunakan alat/bahan atau menganalisa gambar/diagram/skema pada metode eksperimen/non-eksperimen. Guru berupa Dokumentasi kehadiran siswa dan pelaksanaan dan hasil observasi.

Analisis Data secara deskriptif dengan menggunakan tehnik persentase untuk melihat kecenderungan yang terjadi dalam kegiatan pembelajaran. 1) Kognitif (Penguasaan Konsep) : dengan menganalisis nilai rata-rata ulangan harian.Kemudian dikategorikan dalam klasifikasi sangat tinggi, tinggi, sedang, dan rendah. 2) Psikomotor (Peningkatan Keterampilan siswa) : dengan menganalisis hasil observasi Keterampilan siswa dalam merangkai atau menggunakan alat/bahan dan kemampuan membaca/menganalisa gambar/diagram/skema yang diberi petunjuk yang jelas. Selain itu Implementasi peningkatan Keterampilan siswa dalam merangkai atau menggunakan alat/bahan dan kemampuan membaca/menganalisa gambar/diagram/skema yang diberi petunjuk yang jelas: dengan menganalisis tingkat keberhasilan implementasi peningkatan Keterampilan siswa tersebut yang berupa : laporan hasil belajar yang sesuai dengan konsep yang sedang dipelajari dan tepat waktu, kualitas produk makanan fermentasi hasil praktik, kemudian dikategorikan dalam klasifikasi sangat baik, baik, cukup atau kurang.3) Afektif (sikap siswa) : observasi/pengamatan keaktifan siswa dan sikapnya seperti berani bertindak, tidak ragu-ragu lagi, tidak banyak bertanya kepada guru sewaktu praktik dan bekerja sesuai prosedur, dll). Kemudian dikategorikan dalam klasifikasi sangat berhasil (sangat baik),berhasil (baik), kurang berhasil (cukup), dan belum berhasil (kurang). Prosedur Penelitiandilaksanakan secara mandiri, namun tetap bertukar pikiran atau pendapat (berkolaborasi) dengan teman-teman guru BIOLOGI di SMA Negeri 1 Batanghari.Penelitian ini dinyatakan berhasil apabila nilai kognitif mencapai 80 ke atas (kategori tinggi), sedangkan nilai aspek keterampilan dan afektif mencapai 71 ke atas (kategori baik).Indikator Keberhasilansecara keseluruhan deskriptif keberhasilan dari tindakan dalam proses pembelajaran pada setiap pelaksanaan siklus penelitian dapat dilihat pada tabel 1 berikut : 
Tabel 1. Deskripsi Keberhasilan Proses Pembelajaran Pada Setiap Siklus Penelitian.

\begin{tabular}{|c|c|c|c|c|c|c|}
\hline$N$ & Aspek Penilaian & \multicolumn{4}{|c|}{ Dsekripsi Keberhasilan dan Rentang Nilai } & Ket. \\
\hline 1 & $\begin{array}{c}\text { Kognitif } \\
\text { (Penguasaan Konsep) }\end{array}$ & $\begin{array}{c}\text { Rendah } \\
0-59\end{array}$ & $\begin{array}{l}\text { Sedang } \\
60-79\end{array}$ & $\begin{array}{l}\text { Tinggi } \\
80-90\end{array}$ & $\begin{array}{c}\text { Sangat Tinggi } \\
91-100\end{array}$ & \\
\hline 2 & $\begin{array}{c}\text { Psikomotor } \\
\text { (Keterampilan) }\end{array}$ & $\begin{array}{c}\text { Kurang } \\
0-55\end{array}$ & $\begin{array}{l}\text { Cukup } \\
56-70\end{array}$ & $\begin{array}{c}\text { Baik } \\
71-85\end{array}$ & $\begin{array}{c}\text { Sangat Baik } \\
86-100\end{array}$ & \\
\hline 3 & $\begin{array}{l}\text { Afektif } \\
\text { (Sikap) }\end{array}$ & $\begin{array}{c}\text { Kurang } \\
0-55\end{array}$ & $\begin{array}{l}\text { Cukup } \\
56-70\end{array}$ & $\begin{array}{c}\text { Baik } \\
71-85\end{array}$ & $\begin{array}{l}\text { Sangat Baik } \\
86-100\end{array}$ & \\
\hline
\end{tabular}

\section{HASIL DAN PEMBAHASAN}

\section{Hasil Penelitian}

Kegiatan pembelajaran adalah suatu kombinasi yang tersusun meliputi unsur-unsur manusiawi, material, fasilitas, dan prosedur yang saling mempengaruhi untuk mencapai tujuan, (Hamalik, Oemar, 2006). Untuk itulah pentingnya suatu rancangan pembelajaran yang tepat untuk menunjang hal tersebut, yang didahului dengan pepmbentukan kelompok pratikum berikut ini !

Tabel 2. Pembagian tugas praktik per kelompok.

\begin{tabular}{|c|c|c|c|}
\hline No & $\begin{array}{c}\text { Nama } \\
\text { Kelompok }\end{array}$ & Judul Praktikum & Keterangan \\
\hline 1 & F. Redi & LKS 1: Percobaan & \multirow{8}{*}{$\begin{array}{l}\text { Karena Percobaan Spallanzani dan } \\
\text { Pasteur tingkat kesulitannya lebih tinggi, } \\
\text { maka dilakukan oleh } 4 \text { kelompok dan } \\
\text { membuat laporan sesuai percobaan } \\
\text { masing-masing, namun setiap kelompok } \\
\text { harus mencatat data semua percobaan, } \\
\text { dan mempelajarinya juga agar menguasai } \\
\text { konsep secara keseluruhan. }\end{array}$} \\
\hline & & Fransisco Redi & \\
\hline 2 & L. & LKS 2: Percobaan & \\
\hline & Spallanzani & Spallanzani & \\
\hline 3 & L. Pasteur & LKS 2: Percobaan Pasteur & \\
\hline \multirow[t]{2}{*}{4} & Lamarck & LKS 2: Percobaan & \\
\hline & & Spallanzani & \\
\hline 5 & Darwin & LKS 2: Percobaan Pasteur & \\
\hline
\end{tabular}

\section{SIKLUS I :}

Pada siklus pertama, dan pertemuan 1, siswa menggunakan LKS 1 BIOLOGI KD 3.9. (Menjelaskan teori, prinsip dan juga mekanisme evolusi serta pandangan terkini para ahli terkait dengan spesiasi yang sangat bersifat abstrak), yang telah dimiliki, pada konsep mengkomunikasikan hasil studi evolusi biologi (teori-teori asal-usul kehidupan, serta konsep evolusi kimia dan evolusi biologi). Karena masih pertemuan awal, metode yang digunakan berupa studi literatur, Diskusi Kelompok dan presentasi kelompok, karena siswa belum siap dan baru memperkenalkan program dan rencana kedepan (hasil obsernasi keterampilan 66,4 = cukup, sikap 62,2 = cukup, pada lampiran 9).

Pada pertemuan kedua, Percobaan baru dapat dilakukan secara berkelompok, dan ternyata siswa maasih mengalami kesulitan yang ditandai dengan sikap ragu-ragu, selalu bertanya dalam merangkai atau menggunakan alat/bahan, sehingga eksperimen kurang berjalan lancar tanpa bimbingan dan bantuan guru. Hal ini disebabkan karena siswa belum mampu membaca gambar/diagram/skemasusunan perangkat percobaan dalam LKS tanpa penjelasan. Siswa belummemahami apa saja variabel bebas dan variabel kontrol yang harus dipenuhi, sehingga belum dapat merangkai alat dengan benar tanpa bimbingan. Berdasarkan 
kondisi yang demikian, siswa harus diberi penjelasan tentang apa saja variabel bebasnya dan apa pula variabel kontrolnya. Kegiatan ini cukup menyita waktu. (hasil observasi keterampilan 66,4 = cukup, sikap 68,8 = cukup, pada lampiran 10)

Pada pertemuan selanjutnya, LKS menggunakan gambar/diagram yang jelas dengan keterangan gambar yang diperlukan agar pelaksanaan percobaan atau pembelajaran berjalan dengan lancar dan tidak menyita waktu. Dan siklus I diakhiri pertemuan 3 yang membahas Indikator : 3.9.3. dan 3.9.4. mengemukakan hasil studinya tentang proses dan tahapan evolusi kimia dan evolusi biologi (teori fisiko-kimia asal usul kehidupan). mengunakan LKS 4 (Non Eksperimen) dan LKS 5 (prosedur kerja percobaan Stanley Miller) dengan melatih kemampuan membaca/menganalisa gambar/Diagram/Skema, studi literatur dan diskusi kelompok (hasil observasi keterampilan 63,8 = cukup, sikap 79,2 = baik, dapat dilihat pada lampiran 11).

Hasil observasi unjuk kerja (Eksperimen) dan pengamatan kemampuan (membaca/ menganalisa gambar/Diagram/Skema) siswa dalam proses belajar mengajar selama siklus pertama (dari lampiran 12) dapat dilihat pada tabel 3 berikut :

Tabel 3. Perolehan skor dan nilai Keterampilan Siswa Merangkai/menggunakan alat/bahan atau menganalisa gambar/diagram/skema dalam PBM Sklus I.

\begin{tabular}{cccccc}
\hline Kelompok & $\begin{array}{c}\text { Skor } \\
\text { perolehan } \\
\text { rata-rata }\end{array}$ & $\begin{array}{c}\text { Skor } \\
\text { ideal }\end{array}$ & $\begin{array}{c}\text { Persentase } \\
\text { Nilai } \\
\text { Keterampilan }\end{array}$ & Ket. & $\begin{array}{c}\text { Nilai rata- } \\
\text { rata Sikap/ } \\
\text { Keaktifan }\end{array}$ \\
\hline F. Redi & 11,3 & 16 & 71 & & 72 \\
Spallanzani & 10,7 & 16 & 67 & tertinggi & 83 \\
Pasteur & 12 & 16 & 75 & terendah & 67 \\
Lamarck & 9,7 & 16 & 61 & terendah & 67 \\
Darwin & 9,7 & 16 & 61 & & 72,2 \\
\hline \multicolumn{2}{c}{ Rata-rata Kelas } & & 67,0 & & \\
\hline
\end{tabular}

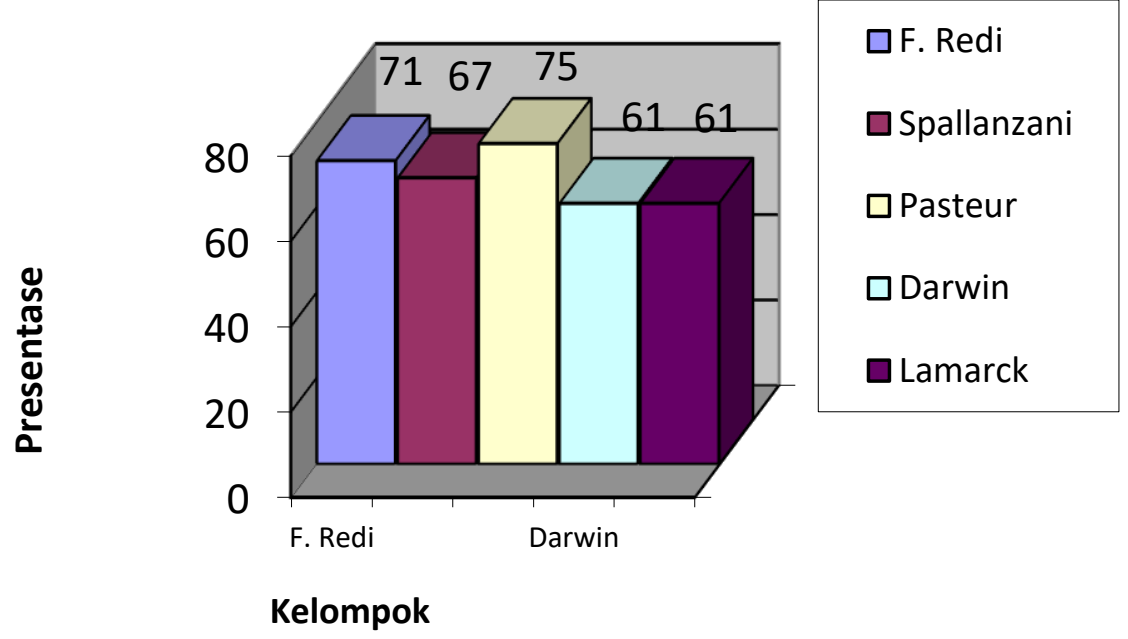

Grafik 1. Perolehan Nilai Ketrampilan dalam PBM Siklus I 
Berdasarkan data di atas bahwa keterampilan dengan nilai rata-rata 67,0 (cukup), nilai sikap/ keaktifan 72,2 (cukup), dan penguasaan konsep (kognitif) dengan pencapaian ketuntasan $0 \%$, dapat disimpulkan bahwa penelitian tindakan kelas ini belum berhasil, sehingga perlu dilanjutkan ke siklus II.

\section{SIKLUS II :}

Dilaksanakan berdasarkan hasil evaluasi dari siklus I, dengan menyempurnakan pembuatan LKS. Gambar alat-alat yang dipergunakan dalam eksperimen/ non eksperimen pada LKS disesuaikan dengan keadaan yang sebenarnya, sehingga lebih memudahkan siswa untuk merangkaikan alat-alat dalam percobaan. Siklus II ini membahas KD3.9. Mendeskripsikan teori, prinsip dan mekanisme evolusi biologi. Pada proses pembelajaaran siklus II ini, sebelum siswa melakukan praktik simulasi seleksi alam terlebih dahulu mempelajari beberapa teori dan prinsip evolusi (LKS 6) karena dominan bersifat teoritis, maka metode pembelajaran menggunakan studi literatur dan diskusi kelompok saja, jadi banyak membaca di rumah sebagai tugas terstruktur.

Pertemuan berikutnya membahas LKS 7 tentang evolusi leher jerapah menurut Lamarck dan Darwin, serta LKS 8 (dua kali pertemuan) tentang petunjuk-petunjuk terjadinya evolusi (kegiatan bersifat Non Eksperimen yaitu menganalisis gambar/diagram/skema). Hasil observasi dengan nilai keterampilan rata-rata 68,2 (cukup) dan sikap 84 (baik/berhasil, ada peningkatan pada sikap dan keaktifan siswa dari 70 menjadi 84), bisa dilihat pada lampiran 13.

Selanjutnya Proses Belajar Mengajar membahas LKS 9, dimana kegiatannya berupa studi literatur, diskusi kelompok dan presentasi, karena bersifat teoritis siswa ditugaskan banyak membaca di rumah (sebagai tugas terstruktur/nilai PR).Siklus II diakhiri dengan melakukan LKS 10 (simulasi seleksi alam) yang menggunakan alat dan bahan sederhana dan perakitannya juga tidak rumit, namun masih ada beberapa kelompok siswa yang mengalami kesulitan dalam hal: a. Keberanian melakukan langkah-langkah kerja yang sudah tercantum dalam LKS dengan mantap, sehingga walaupun sederhana, masih saja bertanya-tanya sebelum bekerja. b. Kemampuan mengolah data yang diperoleh dan menghubungkannya dengan konsep seleksi alam yang sedang dipelajari tersebut, yang ditandai dengan ketidakmampuan siswa umumnya dalam menjawab pertanyaan-pertanyaan di LKS. Hasil observasi menunjukkan nilai keterampilan rata-rata 77,4 (cukup) dan sikap/keaktifan 86 (sangat baik) pada lampiran14.

Untuk mengatasi kesulitan tersebut, selama proses Kegiatan Belajar Mengajar berlangsung guru memberikan bimbingan kepada kelompok siswa yang mengalami kesulitan, dengan menunjukkan cara yang benar dalam melakukan percobaan. Pada akhir siklus II diadakan evaluasi, ternyata hasilnya menunjukkan peningkatan kemampuan siswa dalam merangkai/menggunakan alat/bahanada peningkatan. Untuk siklus selanjutnya LKS diupayakan menggunakan gambar alat yang sebenarnya disertai petunjuk pelaksanaan agar siswa lebih lancar dalam melakukan percobaan. Menurut pendapat Gordon, Thomas, dalam Mudjito (1984) pendidik yang baik dan efektif itu mampu memberikan solusi untuk mengatasi kesulitan belajar siswanya di dalam kelas.

Hasil observasi unjuk kerja (eksperimen) dan menganalisis gambar/diagram/skema dapat dilihat pada lampiran 15 (rekap lembar observasi) selama proses belajar mengajar siklus kedua dan dirangkum pada tabel 4 di bawah ini : 
Tabel 4. Perolehan skor dan nilai Keterampilan Siswa Merangkai/menggunakan alat/bahan atau menganalisa gambar/diagram/skema dalam PBM pada Sklus 2.

\begin{tabular}{cccccc}
\hline Kelompok & $\begin{array}{c}\text { Skor } \\
\text { perolehan } \\
\text { rata-rata }\end{array}$ & $\begin{array}{c}\text { Skor } \\
\text { ideal }\end{array}$ & $\begin{array}{c}\text { Persentase } \\
\text { Nilai } \\
\text { Keterampilan }\end{array}$ & Ket. & $\begin{array}{c}\text { Nilai rata- } \\
\text { rata } \\
\text { Sikap/ } \\
\text { Keaktifan }\end{array}$ \\
\hline F. Redi & 11,3 & 16 & 71 & & 83,3 \\
Spallanzani & 11,3 & 16 & 71 & & 83,3 \\
Pasteur & 12,3 & 16 & 77 & tertinggi & 94,4 \\
Lamarck & 11,3 & 16 & 71 & & 83,3 \\
Darwin & 11,0 & 16 & 69 & terendah & 80 \\
\hline \multicolumn{2}{c}{ Rata-rata Kelas } & & 72,0 & & 84,9 \\
\hline
\end{tabular}

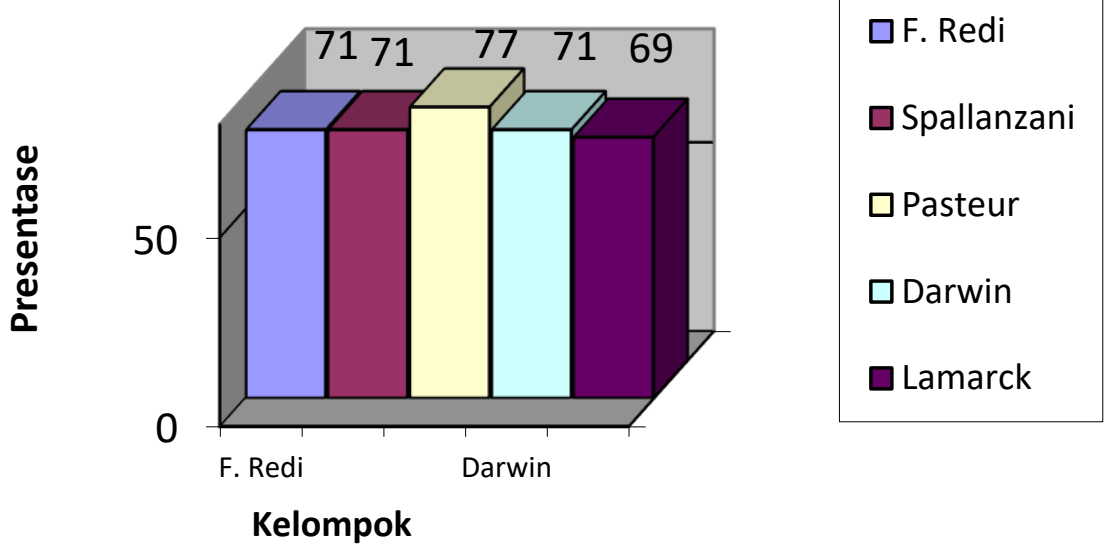

Grafik 2. Perolehan Nilai Ketrampilan dalam PBM Siklus II

Berdasarkan data pada akhir siklus II di atas, dapat disimpulkan bahwa baik nilai keterampilan maupun sikap/keaktifan siswa terjadi peningkaan cukup tinggi, dimana nilai keterampilan rata-rata sebesar 72,0 (baik), sikap/keaktifan 84,9 (baik). Namun nilai kognitif pada ulangan harian 2, siswa yang tuntas 17 orang dari jumlah 29 orang sehingga ketuntasan baru mencapai $58,62 \%$. Keberhasilan penelitian ini belum tercapai, perlu dilanjutkan ke siklus III.

\section{SIKLUS III :}

Siswa diberi LKS tentangKD 3.10 Menganalisis prinsip-prinsip Bioteknologi dan penerapannya sebagai upaya peningkatan kesejahteraan manusi (tentang penerapan bioteknolgi konvensional dalam kehidupan sehari-hari. Indikator: 3.10.4. Membuat produk bioteknologi konvensional, yaitu membuat beberapa makanan fermetasi (tempe, oncom, tape, saukrout dan tauco) yang LKSnya menggunakan gambar asli ataupun skema dan disertai petunjuk pelaksanaan eksperimen/ non eksperimen, siswa tetap diberi bimbingan dalam menggunakan alat dan memilih bahan, namun ada sebagian kecil kelompok 
yang mengalami kesulitan dalam hal :memilih bahan dan ragi yang baik, melakukan langkah kerja tertentu dan waktu yang diperlukan, bekerja secara bersih dan hiegeinis sehingga diperoleh produk makanan yang berkualitas dan terhindar dari tercemarnya mikroba lain yang tidak diharapkan.

Namun sebelum siswa melakukan eksperimen tersebut di atas terlebih dahulu melakukan studi literatur dan diskusi kelompok untuk menguasai konsep dasar bioteknologi dengan bantuan LKS 16, 17 dan 18 yaitu untuk menguasai indikator 3.10.1. s/d 3.10.3. Siswa masih dilatih untuk menguasai konsep dengan banyak membaca dan mengamati gambar/diagram/skema serta melaporkan hasil kegiatannya (sebagai tugas terstruktur).Pada akhir siklus III, siswa diberi quesioner untuk diminta tanggapannya.Hasil observasi unjuk kerja siswa dalam proses belajar mengajar selama siklus III dapat dilihat pada tabel 5 berikut.

$\begin{gathered}\text { Tabel 5. Perolehan skor dan nilai Keterampilan Siswa Merangkai/menggunakan } \\
\text { alat/bahan atau menganalisa gambar/diagram/skema dalam PBM Sklus III. }\end{gathered}$
\begin{tabular}{cccccc} 
Kelompok & $\begin{array}{c}\text { Skor } \\
\text { perolehan } \\
\text { rata-rata }\end{array}$ & $\begin{array}{c}\text { Skor } \\
\text { ideal }\end{array}$ & $\begin{array}{c}\text { Persentase } \\
\text { Nilai } \\
\text { Keterampilan }\end{array}$ & $\begin{array}{c}\text { Ket. } \\
\text { Nilai rata- } \\
\text { rata Sikap/ } \\
\text { Keaktifan }\end{array}$ \\
\hline F. Redi & 13 & 16 & 81 & 100 \\
Spallanzani & 14 & 16 & 88 & & 100 \\
Pasteur & 15 & 16 & 94 & tertinggi & 100 \\
Lamarck & 13 & 16 & 81 & & 100 \\
Darwin & 12 & 16 & 75 & terendah & 80 \\
\hline Rata-rataKelas & & $\mathbf{8 3 , 3}$ & & $\mathbf{9 6 , 0}$
\end{tabular}

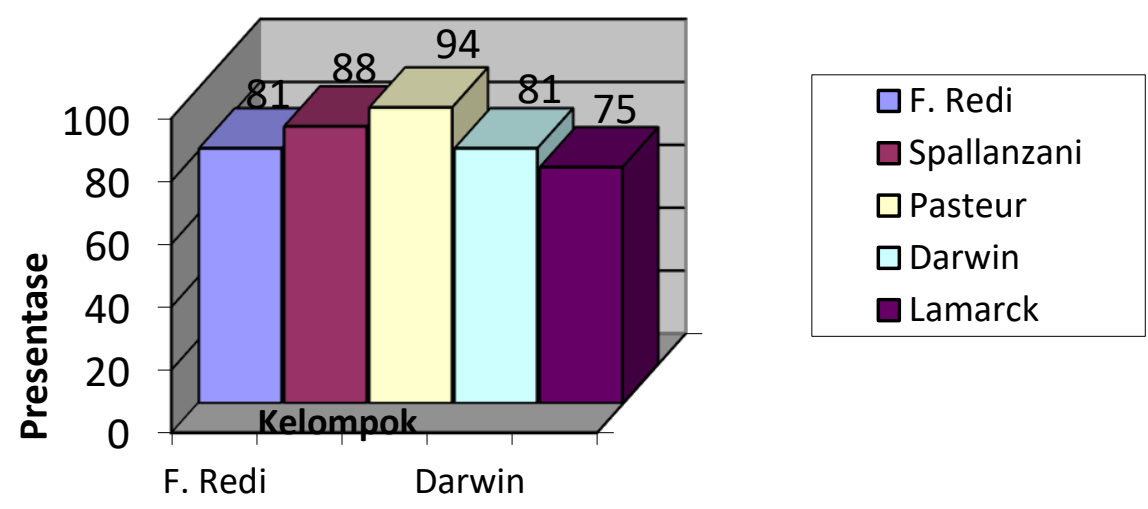

Grafik 3. Perolehan Nilai Ketrampilan dalam PBM Siklus III

\section{PEMBAHASAN}

Pendidikan berbasis kompetensi menekankan pada kompetensi yang harus dimiliki oleh lulusan suatu jenjang pendidikan. Prestasi belajar sains siswa ditentukan oleh kompetensi kognitif, afektif, dan psikomotoriknya, Mulyasa, E. (2003). Salah satu bahan kajian dalam ruang lingkup sains untuk SMA adalah bekerja ilmiah yang meliputi aspek-aspek antara lain; penyelidikan/penelitian, berkomunikasi ilmiah, pengembangan kreatifitas, pemecahan masalah, sikap dan nilai ilmiah. 
Dalam rangka peningkatan mutu pendidikan, perlu penerapan metode pembelajaran yang tepat agar siswa dapat menerima materi pelajaran secara sempurna. Salah satu upaya untuk mencapai tujuan pembelajaran, khususnya mata pelajaran Biologi, perlu penerapan metode eksperimen/non-eksperimen dengan menggunakan LKS. Dengan metode ini siswa dituntut trampil merangkai alat-alat, atau menggunakan alt/bahan praktikum sesuai dengan petunjuk LKS. Namun kenyataan dilapangan dengan metode inipun siswa masih membutuhkan waktu yang ralatif lama, karena selalu bertanya kepada guru setiap mau melakukan kegiatan. Hal ini berarti siswa masih menemui kesulitan dan belum memiliki percaya diri, selalu ragu-ragu dalam bertindak.

Sebagai salah satu mata pelajaran disekolah, sains dengan visi dan misinya yang antara lain berupaya mendidik siswa berilmu dan berketerampilan unggul serta "open minded", memiliki etos kerja, melatih melakukan penelitian sesuai proses/metode ilmiah, dan belajar dengan mengaplikasikan pengetahuan terbaiknya, mempunyai sikap disiplin, jujur dan bertanggung jawab. Disamping itu juga bersikap peka, tanggap dan berperan aktif dalam menggunakan sains untuk memecahkan problem lingkungannya. Melalui penguasaan mata pelajaran sains, baik proses, produk, maupun sikap yang baik, siswa diharapkan mampu mengembangkan ilmunya, bertenggang rasa, mampu membina kerja sama yang sinergis demi tercapainya efisiensi dan efektifitas, kualitas serta kesuksesan nyata bagi siswa, hal ini sesuai Menurut pendapat (Ibrahim, Muslimin. 2000).

Keterampilan Biologi juga menyangkut Keterampilan dalam berkomunikasi seperti: (a) Keterampilan menyusun laporan secara sistematis, (b) menjelaskan hasil percobaan atau pengamatan, (c) cara mendiskusikan hasil percobaan, (d) cara membaca gambar, diagram, grafik atau tabel, dan (e) Keterampilan mengajukan pertanyaan, baik bertanya apa, mengapa dan bagaimana, maupun bertanya untuk meminta penjelasan serta Keterampilan mengajukan pertanyaan yang berlatar belakang hipotesis. Jika aspek-aspek proses ilmiah tersebut disusun dalam suatu urutan tertentu digunakan untuk memecahkan suatu permasalahan yang dihadapi, maka rangkaian proses ilmiah itu menurut Towle (1989) menjadi suatu metode ilmiah.

BIOLOGI sebagai ilmu terdiri dari produk dan proses. Produk Biologi terdiri atas fakta, konsep, prinsip, prosedur, teori, hukum dan postulat. Semua itu merupakan ranngkaian produk yang diperoleh melalui serangkaian proses penemuan ilmiah melalui metode ilmiah yang didasari oleh sikap ilmiah.

Tabel 6. Nilai rata-rata perolehan Keterampilan siswa Merangkai/menggunakan alat/bahan atau menganalisa gambar/diagram/skema dalam PBM serta nilai sikap/keaktifan siswa dari siklus I -III sebagai berikut:

\begin{tabular}{ccccc}
\hline & Siklus & Siklus & Siklus & \\
Nilai & I & II & III & Ket. \\
\hline Keterampilan & 67,0 & 72,0 & 83,4 & \\
Sikap/Keaktifan & 70,0 & 84,9 & 96,0 & \\
\hline
\end{tabular}




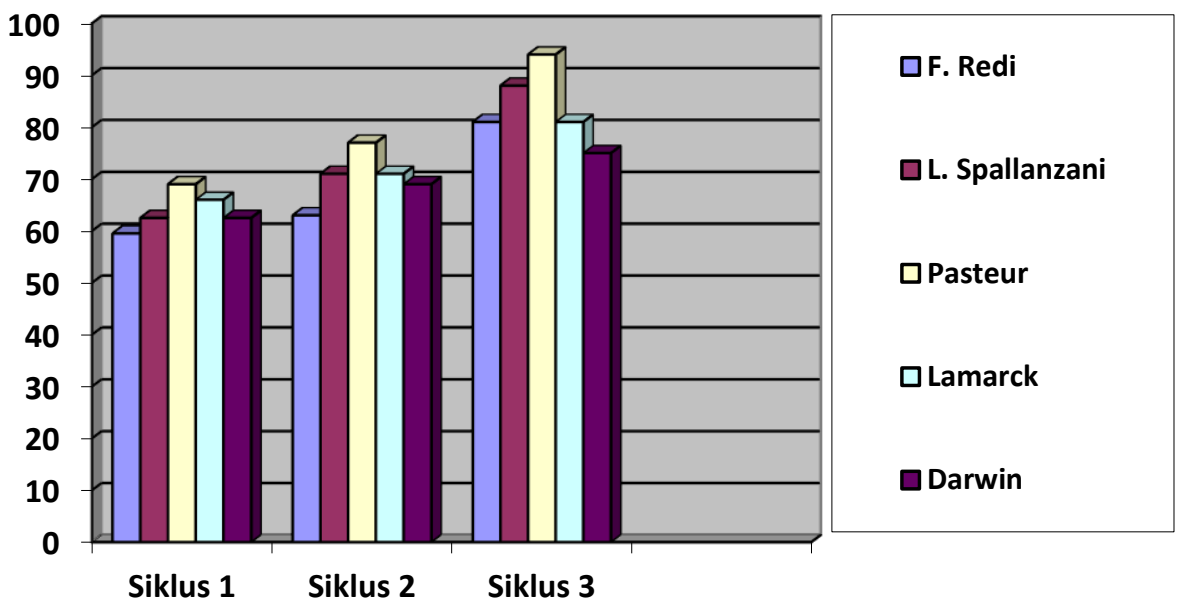

Grafik 4. Perbandingan Nilai Keterampilan Siswa Tiap Siklus (Nilai perolehan Keterampilan siswa Merangkai/menggunakan alat/bahanatau menganalisa gambar/diagram/skema dalam PBM dari siklus I - III)

Tiap satu siklus diakhiri dengan evaluasi yang berupa ulangan harian. Berikut ini hasil nilai rata-rata ulangan harian dari tiap siklus dari 29 siswa yang terlibat dalam PTK.

Tabel 7. Rata-Rata Ulangan Harian Siklus I - III, dengan KKM 75.

\begin{tabular}{lccc}
\hline \multicolumn{1}{c}{ Ulangan Harian } & Siklus I & Siklus II & Siklus III \\
\hline Rata-rata & 58,31 & 74,34 & 80,66 \\
Jumlah Yang & $0(0 \%)$ & $17(58,62 \%)$ & $29(100 \%)$ \\
$\begin{array}{l}\text { Tuntas/ } \% \\
\text { Jumlah Tidak Tuntas }\end{array}$ & $29(100 \%)$ & $12(41,38 \%)$ & $0(0 \%)$ \\
$/ \%$ & & &
\end{tabular}

Tabel diatas yang memuat nilai rata-rata ulangan harian pada tiap siklus, menunjukkan kecenderungan yang meningkat. Hal ini menunjukkan bahwa usaha yang dilakukan dapat mengoptimalkan metode eksperimen/ non eksperimen melalui peningkatan Keterampilan siswa dalam merangkaikan alat-alat percobaan. Selain ulangan harian, evaluasi juga dilakukan dengan kuesioner untuk siswa. Hasil kuesioner terlihat pada tabel dibawah ini.

Tabel 8. Hasil Kuesioner

\begin{tabular}{|c|c|c|c|c|c|c|c|c|}
\hline \multirow{3}{*}{ No } & \multirow{3}{*}{ Pertanyaan } & \multicolumn{7}{|c|}{ Tanggapan dan Jumlah responden (\%) } \\
\hline & & \multicolumn{2}{|c|}{$\begin{array}{c}\text { Tidak } \\
\text { senang }\end{array}$} & \multicolumn{2}{|c|}{ Senang } & \multicolumn{2}{|c|}{$\begin{array}{c}\text { Senang } \\
\text { sekali }\end{array}$} & \multirow{2}{*}{$\begin{array}{l}\sum \text { total } \\
\text { respond } \\
\text { en } / \%\end{array}$} \\
\hline & & $\mathrm{N}$ & $\%$ & $\mathrm{~N}$ & $\%$ & $\mathrm{~N}$ & $\%$ & \\
\hline 1. & $\begin{array}{l}\text { Bagaimana pendapatmu bila dalam } \\
\text { pelajaran Biologimenggunakan LKS? }\end{array}$ & 3 & 10,34 & 18 & 62,07 & 8 & 27,59 & $29=100$ \\
\hline 2. & $\begin{array}{l}\text { Apakah kamu senang pada saat pelajaran } \\
\text { biologi menggunakan Lab? }\end{array}$ & 3 & 10,34 & 14 & 48,28 & 12 & 41,38 & $29=100$ \\
\hline 3. & $\begin{array}{l}\text { Apakah kamu senang melaksanakan } \\
\text { eksperimen/ non eksperimen? } \\
\text { Apakah kamu senang melaksanakan }\end{array}$ & 1 & 3,45 & 18 & 62,07 & 10 & 34,48 & $29=100$ \\
\hline
\end{tabular}


PAEDAGOGY : Jurnal Ilmu Pendidikan dan Psikologi Vol. 1 No. 1 Juni 2021 e-ISSN : 2797-3344 P-ISSN : 2797-3336

\begin{tabular}{llllllll}
\hline 4. $\begin{array}{l}\text { eksperimen/non eksperimen denganLKS? } \\
\begin{array}{l}\text { Apakah kamu senang menggunakan } \\
\text { gambar-gambar skema pada LKS? }\end{array}\end{array} \quad 3,45$ & 17 & 58,62 & 11 & 37,93 & $29=100$ \\
$\begin{array}{l}\text { Apakah kamu senang praktik dengan LKS } \\
\text { 5. }\end{array}$ & 10,34 & 20 & 68,97 & 6 & 20,69 & $29=100$ \\
6. $\begin{array}{l}\text { yangbergambar sesuai benda aslinya? } \\
\text { Apakah kamu senang praktik dengan LKS }\end{array}$ & 2 & 6,90 & 16 & 55,17 & 11 & 37,93 & $29=100$ \\
7. $\begin{array}{l}\text { yang bergambar sesuai aslinya disertai } \\
\text { dengan petunjuk lengkap? }\end{array}$ & 1 & 3,45 & 9 & 31,03 & 19 & 65,52 & $29=100$
\end{tabular}

Tabel diatas menunjukkan bahwa motivasi menggunakan alat/bahan meningkat melalui penggunaan LKS yang mencantumkan gambar dari alat/bahan yang sebenarnya disertai dengan petunjuk yang lengkap dan jelas. Motivasi juga terbukti meningkat tinggi, ditandai dengan siswa mengumpulkan tugas-tugasnya tepat waktu,kecuali kelompok Darwin yang agak terlambat (lebih dari satu minggu). Sehingga sebagai kesimpulan akhir dari penelitian tindakan kelas ini, setelah melalui tiga siklus bahwa : Penelitian Tindakan Kelas ini telah berhasil, karena telah terpenuhinya semua indikator syarat yang ditentukan, sesuai dengan pendapat Madya,Suwarsih,Prof.,Ph.D. (2007). Dengan kata lain bahwa: “Upaya Peningkatan Keterampilan Praktik Untuk Mengoptimalkan Metode Eksperimen/non-eksperimen Pada Siswa Kelas XII IPA-2 SMAN 1 Batanghari”, telah berhasil dengan baik.

\section{KESIMPULAN}

Berdasarkan hasil penelitian dan pembahasan dapat disimpulkan bahwa dengan meningkatkan Keterampilan merangkai atau menggunakan alat/bahan, dan kemampuan menganalisa gambar/diagram/ skema, dapat lebih mengoptimalkan penerapan metode eksperimen/ non-eksperimen sehingga pada gilirannya pula dapat meningkatkan aktifitas dan kualitas hasil pembelajaran Biologisiswa kelas XII IPA-2 SMA Negeri 1 Batanghari.

\section{DAFTAR PUSTAKA}

Brokhous, (1972). dalam Herbert Ovuves, (1996). Kompedium Didaktik Biologi. Jakarta: CV. Rajawali.

Bryce,T.G.K., Mccall, J., MacGregor, J., Roberston, I.,J., \& Weston, R., A., J. (1990). Techiques for Asesing Prosess Skills in Practical Science : Teacher's guide. Oxford: Heinemann Educational Books.

De Porter,Bobbi dan Hernacki,Mike dalam Abdurrahman,Alwiyah (penerjemah), Quantum Learning, Membiasakan Belajar Nyaman dan Menyenangkan, Bandung, Kaifa, 2002.

Gordon,Thomas, dalam Mudjito,Drs.,MA. (Penyadur); Pendidik Yang Efektif, Cara Mengatasi Kesulitan Dalam Kelas, Jakarta, CV Rajawali, 1984.

Hamalik,Oemar,Dr. (1991). Perencanaan dan Manajemen Pendidikan. Bandung: CV Mandar Maju,

Ibrahim, Muslimin. (2000).Pembelajaran Kooperatif. Surabaya: University Press.

Madya,Suwarsih,Prof.,Ph.D. (2006). Teori dan Praktik, Penelitian Tindakan (Action Research). Bandung: Alfabeta.

Mulyasa,E., Dr.,M.Pd., Kurikulum Berbasis Kompetensi, Konsep, Karakteristik dan Implementasi, Bandung, PT. Remaja Rosdakarya, 2003..

Rezba, et al. (2007). Science Proses Skills. United State: Kendal/Hunt Publishing Company.

Soedirman, dkk. (1991). Ilmu Pendidikan. Bandung: Remaja Rosdakarya.

Towle, Albert. (1989). Modern Biologi. Austin : Holt, Rinehart and Winston. 